\title{
FIN DE SIGLO Y MODERNISMO. LA VIRGEN Y LA HETAIRA
}

En Prosas profanas, cuya primera edición apareció en 1896, escribe Rubén Darío:
Mira hacia el lado del boscaje, mira
blanquear el muslo de marfil de Diana
y después de la Virgen, la Hetaira
diosa, su blanca, rosa, rubia hermana (552) ${ }^{1}$.

Diana y Venus, la Virgen y la Hetaira, representan, en este poema (y en el libro en su totalidad), las fuerzas que atraen, y dividen, el alma del poeta. Darío posee la habilidad de penetrar directamente en el corazón de su época y la imaginación del verdadero artista que envuelve su visión en el ropaje retórico preciso. Estas hermanas, que proceden directamente de la iconografía de fin de siglo, son un instrumento metafórico perfecto para comunicar el conflicto espiritual de ese período $\mathrm{y}$, en el mundo hispánico, nos ayudan a entender rasgos esenciales del modernismo.

Mi análisis se va a dirigir a la investigación del significado de la / virgen/ y la /hetaira $/{ }^{2}$. Me parece necesario comenzar con algunas preci-

1 Todas las citas de Rubén Darío por: Rubén Darío, Poesías completas, ed. Alfonso Méndez Plancarte y Antonio Oliver Belmás (Madrid: Aguilar, 1968). Los subrayados, aquí y en citas sucesivas, son míos.

${ }^{2}$ Siguiendo la práctica establecida por la anotación semiótica, cuando un lexema, «virgen» en este caso, es usado en el sentido técnico de «imagen poética», es decir, del «significante» («expresión», en terminología de Eco), se incluye entre rayas diagonales: /virgen/; si, por el contrario, nos referimos al «significado» (al «semema», o, en términos de Eco, al "contenido»), se escribe así: "virgen». Cuando, por otra parte, describo la anécdota de un poema, el lexema no se emplea en sentido técnico y consiguientemente no se señala: «en tal poema Darío describe a la Virgen, en un trono, ... etc.». 
siones metodológicas. Parto de la premisa de que la primera fuente de significación de un texto es el texto mismo. Esta afirmación, que parece una tautología, no lo es. La razón es obvia: la literatura implica la transformación, mediante las figuras retóricas (que son los instrumentos de la función mimética), del sentido denotativo de las palabras. Virgen, en cuanto lexema, denota «mujer que no ha tenido comercio carnal con un hombre»; Hetaira, «mujer que vende su cuerpo». Pero sería ridículo pensar que esas denotaciones agotan el sentido de estos términos, que son piedras angulares de la poesía de Baudelaire, Mallarmé, Darío; de la prosa de Flaubert, de Ganivet, de Unamuno. En cuanto imágenes, /virgen/ y / hetaira/ adquieren significaciones que sólo pueden alcanzarse mediante un esfuerzo interpretativo. Tal esfuerzo requiere un método.

El método que propongo supone tres fases, que pueden ordenarse según los propósitos inmediatos del crítico: 1) Texto/Contexto: el valor poético de /virgen/ y /hetaira/ adquiere una primera determinación mediante el análisis de su significado en la obra del artista que las emplea; es decir, estudiando los distintos contextos en que Darío usa /virgen/ y /hetaira/ en Prosas profanas obtenemos una serie de connotaciones. 2) Texto/Inter-texto: la connotación intertextual se obtiene estudiando el significado de /virgen/ y / hetaira/ en el sistema poético que domina la escritura de fin de siglo. Veremos lo que estas imágenes significaron para Flaubert, Baudelaire y Mallarmé, y cómo las connotaciones obtenidas mediante el análisis intertextual enriquecen enormemente el valor semántico de estas metáforas. 3) Texto/Circunstancia: la última conquista significativa se obtiene al situar el signo literario en un contexto eventual (histórico), más allá del sistema semiótico (literario) al que pertenece. Hasta ahora, /virgen/ y /hetaira/ se han situado en relación con contextos e intertextos, es decir, signos pertenecientes a la escritura, al sistema de la literatura; en el análisis circunstancial trascendemos la semiosis literaria y penetramos en el ámbito histórico: nuevas connotaciones serán obtenidas al situar /virgen/ y /hetaira/ frente a los acontecimientos sociales de la segunda mitad del siglo xix: aparición de la gran ciudad; soledad radical frente a integración social; erotismo exasperado (con frecuencia sádico) frente a las afecciones familiares o colectivas, etc. ${ }^{3}$.

Este método implica una dialéctica. Partimos de un texto inicial que nos proporciona una compleja agrupación de signos (imágenes):

${ }^{3}$ Aunque sintetizo aquí ideas generales de la semiótica moderna, mi fuente principal es Umberto Eco, $A$ Theory of Semiotics (Bloomington: Indiana University Press, 1976); especialmente su revised semantic model, donde Eco modifica los modelos de Katz y Postal y los de Quillian (pp. 95-129). 


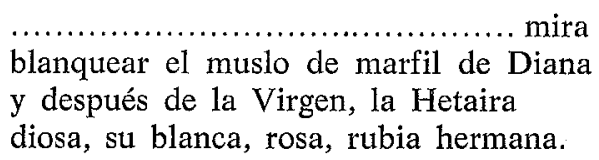

El contraste entre ambas diosas, el predominio exclusivo de / blanco/ en relación con Diana, y la introducción de /rosa/ con respecto a Venus ( $\mathrm{y} / \mathrm{rubia} /=\mathrm{oro}=\mathrm{sol}=$ fuego), nos permiten suponer que a la expresión /blanco/ corresponde el contenido de «castidad», a /rosa/ el de «erotismo». Para comprobar esta hipótesis acudiremos a otros textos de Prosas profanas y veremos que /blanco/ aparece asociado a los signos /eucaristía/, /luna/, /Diana/, /Virgen-María/, y de esa forma nuestra hipótesis se confirma y a «castidad» se asocian otros contenidos: «cristianismo», «separación del mundo», «forma separada de materia», etc. Análogos resultados obtendremos analizando /rosa/. Esta primera etapa interpretativa corresponde a la fase texto/contexto. Mediante nuevas hipótesis que relacionan la /virgen/ y la /hetaira/ a textos de otros autores y a las circunstancias históricas de la época, continuaremos nuestro proceso interpretativo (fases texto/intertexto y texto/circunstancia) y completaremos el sistema del contenido. Pero en cada fase del movimiento dialéctico partimos del texto y regresamos a él. Si, por el contrario, partimos de una definición (por ejemplo, de una interpretación sociológica: división del trabajo en la sociedad industrial; soledad del hombre en el mundo capitalista, etc.) y la aplicamos dogmáticamente a un texto, sin un proceso de análisis, hipótesis y comprobación, apelamos realmente a un acto de fe. La sistemática interpretación socioeconómica del hecho literario pertenece a la ideología y no a la ciencia; es un proceso escolástico y no scholarly. Precisamente porque ha excluido la dialéctica ${ }^{4}$.

${ }^{4}$ Esta afirmación no pretende, claro está, condenar esas interpretaciones socioeconómicas, aunque sí se propone presentar reparos al método dogmático con que generalmente se presentan. Sería injusto negar la pionera contribución de Angel Rama (Rubén Dario y el modernismo [Caracas: Universidad Central de Venezuela, 1970]) a nuestro entendimiento del origen y sentido del modernismo; pero es indudable que su obra es muy desigual. En aquellas secciones en que sigue de cerca los efectos producidos en la profesión de escritor por la división del trabajo en el capitalismo liberal, por la aparición en la vida pública de las masas y su efecto en el periodismo, y especialmente su estudio de la relación del Darío poeta con el Darío periodista (pp. 44-78), Rama escribe magistralmente y su contribución me parece definitiva. Pero cuando enlaza esas conclusiones con categorías tan generales como las relaciones de mercado, burguesía latinoamericana y capitalismo europeo, dependencia económica y estructura literaria, sus conclusiones son mucho más discutibles, como Françoise Pérus ha señalado (Literatura y sociedad en Amé- 
Llamo fin de siglo al movimiento cultural (literario, filosófico, pictórico, etc.) que comienza con Baudelaire y concluye con los movimientos de vanguardia, aproximadamente hacia 1910 (el Primer Manifiesto Futurista, de F. T. Marinetti, aparece en Le Figaro el 20 de febrero de 1909). En cierto sentido, fin de siglo corresponde al amplio movimiento que Georg Lukács llama modernismo, y que, según él, tiene su origen en el triunfo de la revolución industrial, el capitalismo y la democracia libe$\mathrm{ral}^{5}$. Desde la Sturm und Drang hasta los movimientos de vanguardia de principios del siglo $\mathrm{xx}$ tendríamos tres escrituras distintas (tres sistemas icónicos, lenguajes poéticos): la escritura romántica (ruinas, castillos, trovadores, noche y luna, calabozos y ejecuciones), la escritura realista (ciudad; edificios urbanos: mansión, buhardilla, cuartel, oficina; relaciones y conflictos matrimoniales) y la escritura de fin de siglo (mitología clásica, faunos y ninfas, la Virgen, la fermme fatale o hetaira, la esfinge). El sistema icónico de fin de siglo agrupa, pues, una constelación de signos que lo distingue de los anteriores, pero a su vez comprende una serie de movimientos que, aunque comparten con él un núcleo de significación, se distinguen por poner un énfasis especial en ciertos elementos de la expresión o del contenido (parnaso, simbolismo, naturalismo y, en el

rica Latina: el modernismo [La Habana: Casa de las Américas, 1976], pp. 72-89). Ambos críticos se equivocan, en mi opinión, al interpretar el significado de la religión del Arte, núcleo de los movimientos de fin de siglo, precisamente porque parten de presuposiciones teóricas (en este caso de dogmas politicos) y no del texto literario. La praxis escolástica y la exclusión de la dialéctica, les impide comprender el alcance politico mismo de los textos modernistas. Un esfuerzo hacia la balanza entre ideología y análisis literario se encuentra en Noe Jitrik, Las contradicciones del modernismo (México: El Colegio de México, 1978), quien, tras un capítulo introductorio de carácter metodológico, dedica dos («Acento y sonoridad» y «Contar, cantar y decir», pp. 21-62) a examinar varios poemas de Prosas profanas; desgraciadamente, Jitrik, tan agudo e inteligente pensador, no parece haber avanzado, en técnicas literarias, más allá de la estilística tradicional, y los resultados de su análisis no cumplen lo que su ambicioso enfoque prometía. Un caso extremo de confusión y desorden intelectual, producido por una combinación de generalizaciones sociológicas y pobreza analítica, se encuentra en Jean Franco, La cultura moderna en América Latina (México: Joaquín Mortiz, 1971).

${ }^{5}$ Véase, sobre todo, "The Ideology of Modernism», en Realism in Our Time (New York: Harper, 1964), pp. 17-46. Para Lukács, el modernismo se extiende desde Baudelaire hasta el existencialismo y la novela moderna (Kafka, Faulkner y Beckett). Por modernismo, Lukács entiende el movimiento cultural que expresa el individualismo radical, la soledad y desintegración de la persona bajo el capitalismo y en el aislamiento de la gran urbe creada por una industrialización desenfrenada. Pero claro está que ese sentido del modernismo va más allá de cuanto los críticos aceptan en relación con el modernismo como movimiento literario hispánico. 
mundo hispánico, modernismo y noventa y ocho). Según mis supuestos metodológicos, el análisis del núcleo significativo del fin de siglo formará el sistema intertextual que nos permitirá situar al modernismo en un amplio marco histórico cultural ${ }^{6}$.

\footnotetext{
- Modernismo, pues, posee un sentido específico dentro de los estudios hispánicos, aunque sus relaciones con los grandes movimientos culturales, dentro y fuera de las letras hispánicas, han producido una de las más amplias (y fecundas) polémicas de nuestras letras. Para distintas posiciones acerca del modernismo véanse los eruditos trabajos de Alfredo Roggiano, «El origen francés y la valoración hispánica del modernismo», Memoria del IX Congreso del Instituto Internacional de Literatura Iberoamericana (México: Cultura, 1962) y «Modernismo: origen de la palabra y evolución de un concepto», ponencia leída en el XVIII Congreso del Instituto Internacional de Literatura Iberoamericana (Gainesville, 1977). Clásico es ya el excelente estudio de Ivan A. Schulman, "Reflexiones en torno a la definición del modernismon, Estudios críticos sobre el modernismo, Ed. Homero Castillo (Madrid: Gredos, 1968), pp. 325-357. Imprescindibles para una comprensión de las distintas interpretaciones del movimiento son las contribuciones siguientes: Pedro Salinas, «El problema del modernismo en España, o un conflicto entre dos espíritus», Gredos, pp. 23-34; Federico de Onís, «Sobre el concepto del modernismo», Gredos, pp. 35-42; Luis Monguió, «Sobre la caracterización del modernismo» y «De la problemática del modernismo: la crítica y el cosmopolitismo», Gredos, pp. 10-22 y 254-266; así como los artículos de Ricardo Gullón citados más adelante en nota 20. Un artículo pionero hacia direcciones más tarde en boga es el de Yerko Moretic, "Acerca de las raíces ideológicas del modernismo hispanoamericano», en El modernismo, ed. Lily Litvak (Madrid: Taurus, 1975), pp. 51-64. Especial interés tienen para mí el luminoso estudio de Allen W. Phillips, «Rubén Darío y sus juicios sobre el modernismo», Gredos, pp. 118-145, utilísimo para obtener una visión equilibrada de las relaciones de Darío con su intertextualidad americana, hispánica y francesa; y el intuitivo, alegre brindis poético de Saúl Yurkievich, Celebración del modernismo (Barcelona: Tusquets, 1976), quien, al situar el modernismo en la belle époque, y relacionarlo con la sociedad de fin de siglo, sigue una dirección análoga a la que yo presento en este artículo. Para una exposición abarcadora del fin de siglo hispánico véanse: Guillermo Díaz-Plaja, Estructura y sentido del novecentismo español (Madrid: Alianza Editorial, 1975); Emir Rodríguez Monegal, "La generación del 900. Apunte preliminar», en $N u ́-$ mero, 2, 1950, pp. 37-61), y Luis Alberto Sánchez, Balance y liquidación del 900 (Santiago de Chile: Ediciones Ercilla, 1941). Para el erotismo fin de siglo véase Lily Litvak, Erotismo fin de siglo (Barcelona: Antonio Boch, editor, 1979), y Emir Rodríguez Monegal, «Sexo y poesía en el novecientos», en Número, vol. 2, núm. 3, mayo 1964, pp. 90-108. Evidentemente, dada la amplitud del tema, una selección como la que hago aquí por fuerza tiene que ser arbitraria, pero lo que me interesa resaltar es que esa amplia literatura nos permite establecer varias premisas: Darío tiene plena conciencia del carácter renovador de su obra; la influencia de la literatura francesa es decisiva en la dirección que emprende, influencia que es la más importante contribución al «cosmopolitismo» de su arte; la exaltación individual es una de las características esenciales del movimiento; al mismo tiempo, el modernismo se manifiesta como íntimamente unido a (y reflejando) los movimientos sociales de la época.
} 
En el párrafo inicial de este artículo sugerí que la /virgen/ y la /hetaira/ forman el centro de la escritura de fin de siglo; en el que ahora me ocupa intentaré mostrar que estas imágenes, en apariencia puramente retóricas, están profundamente enraizadas en la realidad histórica de la época. Para precisar su sentido analizaré el sistema expresivo (de imágenes) a que pertenecen y el sistema de contenido (de conceptos históricopolíticos) que les corresponde. Ambos sistemas constituyen, pues, la escritura de fin de siglo, que encontró su fuente y crisol en Francia. Tras desentrañar su significado, aplicaremos este sistema intertextual al libro Prosas profanas de Rubén.

En la iconografía de fin de siglo la /virgen/ y la /hetaira/ aparecen intimamente unidas a la terrible y fascinante femme fatale. Este gran arquetipo posee una trascendencia cultural tan vasta que su estudio nos alejaría demasiado de nuestro fin. Me limitaré simplemente a delinear las poderosas fuerzas culturales que contribuyeron a dar su sentido a esta metáfora. Como casi todas las grandes imágenes de fin de siglo, el icón de esa mujer fascinante que es simultáneamente un ángel de belleza y un demonio de ambición y poder, alcanzó su forma moderna en Baudelaire. En «La Beauté» describe así el ideal de belleza de su época:

Je suis belle, ô mortels! comme un rêve de pierre Et mon sein, où chacun s'est meurtri tour à tour Est fait pour inspirer au poète un amour Eternel et muet ainsi que la matière Je trône dans l'azur comme un sphinx incompris J'unis un coeur de neige à la blancheur des cygnes... (24) ${ }^{7}$

En estos versos encontramos ya algunas imágenes que dominarán la imaginación europea (e hispánica). La Belleza se expresa mediante la imagen de una mujer de piedra; también de una esfinge. Estas imágenes contienen las connotaciones de perfección y majestad corporales unidas a dureza espiritual. La atracción destruye (s'est meurtri) a los amantes. La diosa reina desde un trono situado en el azul. Su atracción soberana es tan misteriosa como la de otra gran imagen de piedra: la esfinge. Su belleza corporal, que contiene un corazón de nieve, posee la claridad virginal de ese gran icón, el cisne, resumen y núcleo estético de la época.

En «L'Idéal», Baudelaire añade a estas imágenes algunas notas que precisan su sentido. La mujer-estatua es comparada a «La Noche», de

${ }^{7}$ Las citas de Baudelaire siguen la edición Les fleurs du mal, ed. A. Adam (Paris: Garnier, 1961). 
Miguel Angel, y a Lady Macbeth (emblema, sin duda, del crimen); nos describe, pues, el alma oscura que habita ese cisne puro:

Ce qu'il faut à ce coeur profond comme un abîme c'est vous, Lady Macbeth, âme puissante au crime,

Ou bien toi, grande Nuit, fille de Michel-Ange (25).

Blancura y pureza virginales por una parte y, por otra, oscuridad y crimen, dureza de la piedra y frialdad del hielo; he ahí la semilla del universo poético que nos ocupa.

Pero prosigamos en nuestro examen de la escritura de fin de siglo. Probablemente ningún texto nos ofrece un análisis tan profundo de esa reina de piedra y hielo como la descripción que Flaubert hace de Herodías en el tercero de los Trois contes, "Hérodias». Al aparecer en la narración, Herodías se nos describe señalando especialmente dos rasgos: la oscuridad de sus cabellos, que enmarca la exaltación del triunfo:

[U] ne tresse de ses cheveux noirs lui tombait sur un bras, et s'enfonçait, par le bout, dans l'intervalle de ses deux seins. Ses narines, trop remontées, palpitaient; la joie d'un triomphe éclairait sa figure $(146)^{8}$.

$\mathrm{Su}$ triunfo consiste en el encarcelamiento de su propio hermano, Agripa, por Tiberio. Como Agripa es un posible rival para el título de rey de Galilea, Herodías ha utilizado la belleza de su hija Salomé para seducir al espía Eutiques, que ha denunciado a Agripa al emperador. Herodías se propone ahora hacer que su hermano sea asesinado.

Herodías es, evidentemente, esa «âme puissante au crime». Con unas pinceladas maestras Flaubert nos presenta la imagen de una mujer de energía demoníaca. Los lazos familiares son esenciales para señalar la enormidad de sus crímenes: incestuosa en su matrimonio con HerodesAntipas, ha traicionado e intenta hacer asesinar a su hermano, y para ello hace que su hija Salomé se prostituya. En su individualismo feroz, se sitúa más allá de la ley, de la norma ética, del Bien y de Dios. Solamente su sobrehumana voluntad de poder, la expresión de su soberana personalidad, dirige sus acciones: en ella se encarna una pasión absoluta, una libertad divina o diabólica. El crimen, pues, llevado a dimensiones monstruosas, es una marca de grandeza.

${ }^{8}$ Gustave Flaubert, Trois contes, ed. Edouard Magnial (Paris: Garnier, 1969). 
Esa grandeza alcanza su cima en el asesinato de San Juan Bautista. Apropiadamente, el marco material del crimen es descrito por Flaubert como un templo del vicio:

Les convives emplissaient la salle du festin. Elle avait trois nefs, comme une basilique, et que séparaient des colonnes en bois d'algumim, avec des chapiteaux de bronze converts de sculptures (181).

La mesa real, y no un altar, preside este templo. Potestades terrenales la ocupan: Herodes y los representantes del poder romano, Lucius Vitellius y su hijo Aulus, el futuro emperador que se convertiría en horrendo prototipo de glotonería y lujuria. El poder, el vicio y el crimen reemplazan, en ese sacrílego retablo, la presencia divina del sagrario. $\mathrm{Y}$ aquí, usando de nuevo la belleza de su hija Salomé para inflamar de lujuria a su marido Herodes-Antipas, Herodías realiza su crimen supremo: la decapitación del Bautista, el precursor de Cristo. Más allá del incesto, de la traición y el fratricidio, el «âme puissante au crime» ha llevado el desafío a la misma morada de Dios.

En su introducción a los poemas de Mallarmé, Sartre escribe:

Mallarmé sent croître en lui de bonne heure un révolte que ne trouve pas son point d'application... Bien sûr, il faut faire sauter le monde: mais comment y parvenir sans se salir les mains...? Mallarmé n'est pas, ne sera pas anarchiste: il refuse tout action singulière; sa violence - je le dis sans ironie- est si entière et si désespérée qu'elle se change en calme idée de violence. Non, il ne fera pas sauter le monde: il le mettra entre parenthèses $(5)^{9}$.

El cosmos, para Mallarmé, se divide en dos zonas: una inferior, donde reinan la estupidez y la náusea, y otra celeste, la región del azul:

Ainsi, pris du dégoût de l'homme à l'âme dure

Vautré dans le bonheur, où ses seuls appétits

Mangent

Et le vomissement impur de la Bêtise

Me force à me boucher le nez devant l'azur.

(Du Parnasse contemporain, "Les fenêtres», 29.)

Aunque ambos, Flaubert y Mallarmé, están dándonos 1a expresión poética de los ideales de su época, los versos de Mallarmé nos permiten

\footnotetext{
Stéphane Mallarmé, Poésies, Préface de Jean-Paul Sartre (Paris: Gallimard, 1969).
} 
asociar mucho más directamente su náusea con las transformaciones industriales, con las fuerzas económico-sociales de finales del diecinueve. El vomissement impur de la Bêtise se asocia con ese humo de las fábricas tristes que han convertido el mundo en una prisión y han matado el cielo del arte (el azul):

Encor! que sans répit les trites cheminées Fument, et que de suie une errante prison Eteigne dans l'horreur de ses noires traînées Le soleil se mourant jaunâtre à l'horizon! -Le Ciel est mort- («L’Azur», 38).

Mallarmé, nos ha dicho Sartre, se rebela contra ese mundo poniéndolo entre paréntesis. La expresión icónica de esa rebelión, de ese alejamiento radical, es la imagen de la Virgen. La castidad y la virginidad son la expresión imaginaria de ese horror a la contaminación de la sociedad de su época; sólo una pureza absoluta puede liberarnos del vómito de la bestia. Sorprendentemente, Mallarmé utiliza como /virgen/ a Salomé (a quien llama por el nombre de su familia, Hérodiade); de esa forma une en un solo icón los dos aspectos de la mujer fatal, la pureza de la forma y la dureza infernal del alma. Al identificar a Hérodiade con Diana y con la luna, Mallarmé une la virginidad con la helada blancura dèl astro; al identificarla con la serpiente apunta a su voluntad demoníaca:

J'aime l'horreur d'être vierge et je veux

Vivre parmi l'effroi que me font mes cheveux

Pour, le soir, retirée en ma couche, reptile

Inviolé sentir en la chair inutile

Le froid scintillement de ta pâle clarté

Toi que te meurs, toi qui brûles de chasteté,

Nuit blanche de glaçons et de neige cruelle!

Et ta soeur solitaire, ô ma soeur éternelle,

Mon rêve montera vers toi... (54).

Las imágenes que hemos examinado forman el núcleo del sistema poético de fin de siglo. Su estudio nos proporciona el marco semiótico que nos permitirá obtener connotaciones determinantes en el análisis de los textos de Darío. Tales imágenes se ordenan en dos sistemas centrados en la /virgen/ y la /hetaira/. A la /virgen/ corresponden el /azul/, donde la Virgen reina sobre un trono (la iconografía de la tradición cristiana no puede ser más clara); /Diana/ y la /luna/ con su blancura que ilumina la oscuridad sublunar (es decir, del mundo oscuro de humo, 
fábricas y vómitos); el /cisne/, que nada también en el azul. Frente a esa constelación encontramos otra que gira alrededor de la /hetaira/: /Lady Macbeth/, con todas sus connotaciones de voluntad indomable y de alma criminal; /la Noche/, que se opone a la blancura del cisne, de Diana y de la luna; /la esfinge/ animal cruel y destructor en la mitología de fin de siglo ${ }^{10}$; la /estatua/ imagen de la dureza criminal. Finalmente, la morada de la /hetaira/ es el templo sacrílego de la sensualidad y el poder, del vicio y el crimen, que se adornan con las riquezas de la naturaleza (joyas, oro, alabastro, etc.) y se ponen al servicio de una diosa implacable.

Todo sistema expresivo es un conjunto de signos al que corresponde un sistema de contenidos. Las estructuras filosóficas, políticas y estéticas expresadas por ese sistema icónico han sido sugeridas en el examen de los textos citados; las resumiré brevemente ahora. La visión que domina ambos sistemas es la de división del cosmos en dos zonas, una inferior, una oscura prisión de humo, fábricas, oscuridad y vómito; otra superior, el azul, donde habitan la Belleza y el Poder. A estas dos potestades (que deliberadamente reemplazan al dios cristiano) corresponden la /virgen/ y la /hetaira/. La /virgen/ connota, en primer lugar, la incontaminación de ese mundo inferior: frente a la civilización industrial (luego veremos que también frente a la masa, el liberalismo y la democracia), la /virgen/ representa la Belleza inmaculada del arte aristocrático, o la pureza de una tradición no manchada por la civilización contemporánea; pero a esa connotación primaria se unen las de divinidad y, consiguientemente, soberanía. La connotación primaria de la / hetaira/ no es sensualidad, sino poder; su culto pone el imperio en el lugar del cordero eucarístico (es decir, Herodes y Vitellius en el altar), y su ritual es el crimen. Pero ¿qué sentido tiene decir que el crimen es el rito que corresponde al culto del imperio? La situación de este esquema significativo en la ideología de la época nos lo aclara: Herodías debe violar las leyes maternales, fraternales, sociales, porque mediante esas infracciones rituales se muestra la superioridad del individuo frente a cuanto lazo lo une a la sociedad; es decir, el individuo aparece como fuente única de la ley, no ya

${ }^{10}$ Las relaciones entre las imágenes aquí estudiadas, así como con las situaciones de tortura y violencia que las acompañan, se convierten a fines del siglo XIX en un lenguaje común a todas las artes: A. Symons, From Toulouse Lautrec to Rodin (London: Lane, 1929); W. Gaunt, The Aesthetic Adventure (London: Cape, 1945); J. Bricau, Huysmans et le satanisme (Paris: Chacornac, 1913), y H. Trudgian, L'esthétique de Joris Karl Huysman (Paris: Conard, 1934). El mejor estudio general sobre el desarrollo y evolución de esas imágenes en el siglo XIX es el de Mario Praz, The Romantic Agony (London: Oxford University Press, 1970). 
social, sino moral y, en último extremo (puesto que su voluntad es absoluta y creadora), divina. La divinización del individuo, frente a la organización democrática de la sociedad (una sociedad concebida como masa repulsiva) es la significación última de la /hetaira/. La /virgen/ y la /hetaira/ constituyen, pues, dos polos de la religión de la Belleza y del Superhombre; sus templos son los del Arte o el Poder. Herodías es la semilla de donde brotarán futuros líderes, poderosos y supremos, situados más allá del crimen. Pero ni el Artista ni el Superhombre están solos. El Artista, sacerdote del Templo del Arte, comunica su visión, mediante la mágica plegaria del verso, a un grupo de elegidos, un cenáculo órfico. El Superhombre, aliándose a otros aristócratas del Ideal, impondrá, mediante la acción brutal y decidida (herodiana) ese Ideal a las mezquinas masas democrático-liberales ${ }^{11}$.

La escritura correspondiente a un movimiento literario posee un núcleo significativo sobre el que nuevas versiones imponen connotaciones originales. Darío mantiene el núcleo esencial del sistema poético de fin de siglo; pero le añade las connotaciones circunstanciales que corresponden a la América española de su tiempo. La versión de Darío es de una originalidad y una riqueza deslumbradoras. Acabamos de mostrar que la poética de fin de siglo implica un ataque al cristianismo tradicional: contra el templo cristiano se alza el templo del Arte o el del Poder; al cordero sacrificado se opone el Artista ${ }^{2}$ o el Superhombre; a la sumisión del individuo a lo Absoluto se opone la divinización de ese individuo, que se convierte en norma y origen de autoridad ilimitada. $Y$ ese individualismo desenfrenado se expresa, hemos visto, mediante un sistema poético que tiene como centro dialéctico la velación entre la /virgen/ y la /hetaira/. El texto que más perfectamente expresa ese sistema es Prosas profanas.

Apropiadamente, Prosas profanas se presenta como una oración, pero una oración pagana. Su tema es un conflicto entre la Eucaristía y el Falo (divinizado como encarnación de Eros); conflicto que se expresa también mediante las oposiciones de Dios y Pan, de Diana (la diosa virgen) y de Venus (su hetaira hermana). Aunque ésta pueda parecer una interpretación sorprendente del gran poema de Darío, se trata en realidad de una lectura obvia, claramente apoyada por un atento examen del texto. Un

${ }^{11}$ Evidentemente, Nietzsche es la mayor influencia tras esas ideas; pero con él también Wagner, Ibsen y, sobre todo, D'Annunzio, a quien Darío cita como maestro en Prosas profanas (en «Garçonnière», p. 567).

${ }_{12}$ Para un paralelo Cristo-Artista véase «Bénédiction» de Batudelaire, Garnier, p. 9. 
estudio del libro entero trascendería los límites de este artículo; me limitaré, pues, a analizar las «Palabras preliminares» y algunos fragmentos.

Las «Palabras preliminares» nos interesan especialmente porque Darío presenta en ellas el marco que encierra los poemas que forman el libro; ese marco resume sus temas principales. El poema se ofrece deliberadamente como un texto religioso. El Arte es un templo al que sólo una minoría aristocrática tiene acceso. El poeta es un «monje artífice»; la luz llega a esa selecta comunidad a través de «vidrieras historiadas»; fuera sopla el viento de la vulgaridad. La creación de su obra es significada mediante la metáfora de la misa: Darío, sacerdote, recita su «misa rosada» y sus poemas son «antífonas», «secuencias», «prosas» (en el sentido de himnos que se cantan antes del ofertorio). La armonía de sus versos corresponde a las campanas del templo: «campanas de oro, campanas de plata» que llaman a su fiesta pagana. Lo esencial de esta religiosidad blasfema consiste en reemplazar el evangelio cristiano por uno nuevo, greco-francés, en el que el altar es presidido por Venus; a ella rinden homenaje los «incensarios» de Darío. Esta religión estética es no sólo aristocrática, sino también salvaje ${ }^{13}$ : nace de un monje que se define como uniendo «sangre de indio» a "manos de marqués». Como tal, su evangelio no es para las vulgares masas democráticas; su mensaje es imperial:

[Y]o detesto la vida y el tiempo en que me tocó nacer; y a un presidente de la República no podré saludarle en el idioma en que te cantaría a ti, ioh Halagabal!, de cuya corte —oro, seda, mármol- me acuerdo en sueños. (Si hay poesía en nuestra América, ella está en las cosas viejas: en Palenke y Utatlán, en el indio legendario y en el inca sensual y fino, y en el gran Moctezuma de la silla de oro. Lo demás es tuyo, demócrata Walt Whitman (546) ${ }^{14}$.

El origen de este aristocratismo religioso está claro tras nuestro análisis de los maestros franceses. Darío sabe lo que hace cuando insiste en su independencia frente a España: «Abuelo, preciso es decíroslo: mi esposa es de mi tierra; mi querida, de París» (547) ${ }^{15}$.

${ }^{13}$ Salvaje, por supuesto, no tiene aquí significado peyorativo: véase nota 21 .

${ }^{14}$ El enlace de Palenke, Utatlán, Moctezuma y Halagabal identifica el sueño imperial con la sangre india y el gran arquetipo del poder, Roma. A esa grandeza se opone la vulgaridad del presidente de la República y de la cultura democrática (Walt Whitman).

${ }^{15}$ No todos los críticos aceptan las consecuencias de la tajante afirmación de Darío: véase Donald F. Fogelquist, «El carácter hispánico del modernismo», Gredos, pp. 66-74. 
En el seno de esta religión aristocrática se enfrentan la /virgen/ y la /hetaira/. En Darío el conflicto tiene un contenido erótico que se expresa mediante las constelaciones icónicas que rodean estas dos imágenes centrales. La /virgen/ tiene como imágenes subordinadas la /luna/, /Diana/, la /nieve/ y, sobre todo, el /cisne/. Todas ellas, como vemos, son integradas por una unidad estructural, la /blancura/. A su vez, la /luna/ y la /blancura/ se funden en el icón que desempeña, naturalmente, un lugar fundamental en la misa rubeniana: la /eucaristía/:

El olímpico cisne de nieve con el ágata rosa del pico lustra el ala eucarística y breve que abre al sol como un casto abanico (557).

El ala del cisne aparece como un «casto abanico»; es decir, la imagen transforma al cisne en una casta doncella que abre un abanico; simultáneamente, la figura circular del abanico abierto y la calificación de «casta» imponen sobre el cisne-doncella la imagen de la hostia: la eucaristía preside sobre ese mundo de blancura. Pero esa blancura se rompe por un pico rosa. Si la afirmación de que ese pico es un símbolo fálico puede parecer aventurada, el examen de otros textos de Prosas profanas nos fuerzan a aceptar esta hipótesis.

En «Bouquet» Rubén describe el deseo erótico hacia una angélica joven («blanco serafín») como la profanación de su blancura sacramental por una rosa roja. El poema está lleno de la imaginería blasfema tan característica de los decadentes franceses. El nombre de la joven virgen («tus bodas de virgen con el sueño son») es Blanca; su blancura es comparada a la cera de los cirios (connotación evidentemente religiosa) y a la espuma del océano (connotación pagana: de esa espuma, como Rubén aclara más tarde, nació Venus): "Cirios, cirios blancos, blancos, blancos cirios /.../ galas de la espuma, ceras de los cirios». Esta blancura conventual es «manchada» (evidentemente en el sentido de profanada) por el deseo erótico del poeta:

Yo, al enviarte versos, de mi vida arranco la flor que te ofrezco, blanco serafín. iMira cómo mancha tu corpiño blanco la más roja rosa que hay en mi jardín! (564).

La blancura angelical se mancha con el rojo de la rosa. Hemos visto antes que esa blancura tenía un carácter sacramental; veamos si podemos afirmar que, frente a ella, el color rojo es un paradigma del erotis- 
mo. La clave de este eje semántico, que polariza la imaginación de Prosas profanas (como el de la /virgen/ y la /hetaira/, al que corresponde), se encuentra en estos versos del «Coloquio de los centauros»:

Cuando del sacro abuelo la sangre luminosa con la marina espuma formara nieve y rosa hecha de rosa y nieve nació la Anadiomena (575).

La «sangre luminosa» del "sacro abuelo» es una determinación tan clara del principio erótico como Darío, dentro de la estética modernista, puede darnos. Se trata, claro está, del pene de Urano, que, castrado por su hijo Cronos, cae al mar, cerca de Chipre, y de él, mezclado con la espuma marina, nace Venus (la Anadiomena). Esa sangre, para mayor precisión, es llamada rosa. El / rojo/, pues, es un arquetipo de Eros, representa el pene divino, y se incorpora en múltiples estructuras icónicas como la /rosa/, el / pico-del-cisne/, etc. ${ }^{16}$.

El último poema que voy a mencionar, el soneto «Ite, missa est», nos resultará transparente en este contexto. Este soneto es una de las claves significativas del libro: la misa sacrílega constituye el ritual que el "monje» Darío ejecuta en el templo del Arte; ritual que consiste en la transformación de Diana en Venus, de la Virgen cristiana en la «faunesa antigua». Esta misa, como la famosa de Huysmans, es realmente una misa negra, una profanación de la eucaristía:

Yo adoro a una sonámbula con alma de Eloísa, virgen como la nieve y honda como la mar; su espíritu es la hostia de mi amorosa misa, y alzo al son de una dulce lira crepuscular.

Ojos de evocadora, gesto de profetisa, en ella hay la sagrada frecuencia del altar; Su risa es la sonrisa suave de Monna Lisa, sus labios son los únicos labios para besar.

$\mathrm{Y}$ he de besarla un día con rojo beso ardiente; apoyada en mi brazo como convaleciente, me mirará asombrada con íntimo pavor;

${ }^{16}$ Mi interpretación se acerca a la expuesta por Octavio Paz en su brillante ensayo «El caracol y la sirena», Cuadrivio (México: Joaquín Mortiz, 1965); Paz escribe que «Los arquetipos de su universo son la matriz y el falo» (p. 59); estoy de acuerdo, pero la matriz tiene, creo, unas dimensiones que Paz sugiere pero no examina. Yo he intentado hacerlo mediante el análisis de las imágenes en que Diana y Venus se presentan en Prosas profanas. 
la enamorada esfinge quedará estupefacta, apagaré la llama de la vestal intacta, iy la faunesa antigua me rugirá de amor! (571).

Una lectura cuidadosa de Prosas profanas nos mostraría que Dario no proclama la destrucción de la Virgen, sino su fertilización, su dinámica transformación mediante la energía erótica. Pero meditemos un momento en el atrevimiento de su visión: Darío es un monje en un templo, y en su altar celebra una misa que consiste en la posesión sexual de la Virgen, a la que comunica su fervor erótico. Que esta visión tiene un primario sentido religioso es evidente por la estructura de su iconografía. Octavio Paz ha visto claramente que en Darío se da una religiosidad pagana de dimensiones cósmicas; para Darío, la Mujer (quizá mejor la Hembra; el principio erótico femenino) es el origen de una experiencia en cierta forma mística, de una exaltación emocional por la que se revela al hombre el sentido del universo, de la vida y del arte ${ }^{17}$. Pero a esta visión religiosa corresponde una revolución estética; Rubén tiene conciencia de guiar en el mundo hispánico una renovación poética que participa de esa tremenda translocación de valores que caracteriza su misa erótica. He aquí un programa en que se expresa esa conciencia:

Fue en una hora divina para el género humano.

E1 cisne antes cantaba sólo para morir

Cuando se oyó el acento del cisne wagneriano

fue en medio de una aurora, fue para revivir.

¡Oh Cisne! ¡Oh sacro pájaro! Si antes la blanca Helena

del huevo azul de Leda brotó de gracia 1lena,

siendo de la Hermosura la princesa inmortal,

bajo tus blancas alas la nueva Poesía

concibe en una gloria de luz y de armonía

la Helena eterna y pura que encarna el ideal.

(«E1 Cisne», 527.)

La «nueva Poesía» (capitalizada para resaltar su sentido religioso) es comparada al ideal eterno de belleza personificado en Helena, a quien se la enlaza sutilmente con la Virgen («brotó de gracia llena»). Wagner,

${ }_{17}$ Octavio Paz, Cuadrivio: «Su cosmología culmina en un misticismo erótico: hace de la mujer la manifestación suprema de la realidad plural y endiosa al semen» (p. 57); "La mujer es anterior a Cristo: lava todos los pecados, disipa todos los miedos...» (p. 59). 
uno de los maestros del movimiento finisecular, es el padre (a través de su Cisne) de esta nueva encarnación de la Helena eterna, del nuevo ideal ${ }^{18}$.

Esta identidad de la Virgen y Helena es confirmada en el «Coloquio de los centauros», donde la belleza ideal, eterna, se presenta bajo la forma de Diana, uno de los dos principios que rigen la vida cósmica (el otro, claro, es la / hetaira/, Venus). Diana y Venus, como la muerte y la vida ${ }^{19}$, rigen el cosmos y la historia. La iconografía de Diana, descrita como una doncella con una corona de estrellas, nos recuerda (deliberadamente sin duda) una virgen de Murillo:

Es semejante a Diana, casta y virgen como ella; en su rostro hay la gracia de la núbil doncella y lleva una guirnalda de rosas siderales (578).

En la contemplación de las ninfas de Diana se origina la creación estética:

El vate, el sacerdote, suele oír el acento

desconocido; a veces enuncia el vago viento

un misterio

Y el hombre favorito del numen, en la linfa

o la ráfaga, encuentra mentor: demonio o ninfa (574).

Las imágenes religiosas persisten: el poeta es vate o sacerdote; la inspiración, como el Espíritu Santo, es una ráfaga, un viento que procede de esas ninfas vislumbradas por el centauro (el carácter pagano de esa religiosidad es sugerido por la ambigua comparación de la ninfa al demonio). Esa visión nos explica la significación última de la imagen del centauro, central en Prosas profanas; el vate es un ser prodigioso: mitad dios y mitad bruto; es divino por su capacidad de alzarse a la altura y vislumbrar la belleza de Diana:

${ }^{18}$ Tenemos, pues, un acto arquetípico e intemporal: fecundación divina de Leda por el Cisne y nacimiento de la Belleza eterna. Esa belleza es fecundada en el tiempo por los grandes vates: Wagner engendra en ella un nuevo Cisne, que a su vez concibe «la nueva Poesía», es decir, la poesía modernista. La importancia del /cisne/ en el fin de siglo es confirmada por la universalidad de esta imagen, como ha mostrado Esperanza Figueroa-Amaral en su erudito artículo «El cisne modernista», Gredos, pp. 299-315.

${ }^{19}$ Diana como muerte significa el reino de la Belleza eterna que trasciende, en cuanto tal, la vida; pero, sin embargo, la fecunda. Estas ideas se analizan más tarde en mi artículo. 
El biforme ixionida comprende de la altura, por la materna gracia, la lumbre que fulgura, la nube que se anima de luz y que decora el pavimento en donde rige su carro Aurora, y la banda de Iris que tiene siete rayos cual la lira en sus brazos siete cuerdas...

Sus cuatro patas bajan; su testa erguida sube (574).

El movimiento ascendente significa la contemplación poética de la lira eterna, la eterna armonía, Diana o Helena. Pero lo eterno, en cuanto trascendente, es muerte si no se encarna, por la actividad erótica de vate, en la historia. Ese principio de descenso es la animalidad del creador: las patas que, en oposición a la testa, «bajan».

Detengámonos un momento en el /centauro/. ¿Está Darío dándonos aquí una visión intemporal de la religión del Arte? En el «Coloquio de los centauros», evidentemente, así es. Pero el /centauro/ es un icón; una estructura poética que se incorpora funcionalmente a distintos contextos. Un examen de dos de ellos nos muestra que, aparte de ese sentido arquetípico, el /centauro/ tiene para Rubén claras connotaciones históricas. En «Del campo» esa encarnación en la realidad contemporánea no puede ser más extrema: Rubén recuerda el «regio Buenos Aires», y nos presenta el encanto decadente de una calle Florida que "mira pasar la Gloria, la Banca y el Sport»; los ensueños se han rebajado a una poesía para nuevos ricos: «Rigiendo su cuadriga de mágicas libélulas / de sueños millonarios pasa el travieso Puck». Toda la belleza de la naturaleza y de la ciudad aspiran a un poeta capaz de cantarlas ( «iLástima que falte el ruiseñor!»). Con tremenda fuerza Darío presenta repentinamente la visión de un centauro gaucho que, trayendo consigo el dolor de su historia, encarna el principio de la «Poesía» indígena:

De pronto se oye el eco del grito de la pampa;

brilla como una puesta del argentino sol;

y un espectral jinete, como una sombra cruza, sobre su espalda un poncho, sobre su faz dolor.

— ¿Quién eres, solitario viajero de la noche?»

- "Yo soy la Poesía que un tiempo aquí reinó:

iYo soy el postrer gaucho que parte para siempre,

de nuestra vieja patria llevando el corazón!» (559-560).

Que ese «postrer gaucho» es Darío es evidente. Lo que nos interesa especialmente es el enriquecimiento histórico que este texto introduce en el /centauro/. Ese principio erótico encarna aquí en el gaucho, en el 
prototipo de una cultura indígena, vital, cuya energía se enfrenta con esa cultura vulgar que inunda Buenos Aires. La revolución estético-erótica capaz de crear un mundo nuevo supone así un renacimiento de «el indio legendario y el inca sensual y fino», que se enfrenta al demócrata «presidente de la República» ${ }^{20}$. Y, no lo olvidemos, ese indio es también el imperial Moctezuma (frente al «demócrata Walt Whitman»). La vulgaridad burguesa del Buenos Aires de su época corresponde, pues, a la democracia liberal; la nueva poesía, que traerá una renovación cósmica, es al mismo tiempo radicalmente conservadora (retorno al pasado grandioso indio) y revolucionaria, prometedora de un futuro imperial.

Lo que fueron esos movimientos revolucionarios que prometían la renovación de imperios pasados en nombre de la sangre y la raza no necesita aclaración. Por si cupiera alguna duda, Darío mismo nos presenta, en "Garçonnière», a un grupo de aristocráticos centauros inspirados por Diana y Venus: se trata de jóvenes de la aristocracia bonaerense que se han reunido en un piso de soltero para oír la lectura de D'Annunzio que les hace Rubén. Los jóvenes aparecen envueltos por los emblemas del pasado imperial español: los colores de la bandera española tapizan las paredes cubiertas de reliquias aristocráticas («Los tapices rojos, de doradas listas, / cubrían panoplias de pinturas y armas / que hablan de bellas pasadas conquistas»); los versos de D'Annunzio comunican un brutal entusiasmo a esos jóvenes, incitándolos a revivir las pagadas saturnales y transformándolos en salvajes acólitos del culto de Venus:

\author{
E iban con manchadas pieles de pantera ${ }^{21}$, \\ con tirsos de flores y copas paganas \\ las almas de aquellos jóvenes que viera \\ Venus en su templo...
}

${ }^{20}$ En este sentido de arquetipo de un pasado imperial deben interpretarse, creo, las acertadas sugerencias de Ricardo Gullón en «Indigenismo y modernismo» y «Erotismo y modernismo», Gredos, pp. 267-298.

${ }^{21} \mathrm{La} /$ pantera/ aparece asociada a danzas y rituales religiosos en «Divagación»: «O con amor hindú que alza sus llamas / en la visión suprema de los mitos / y hace temblar en misteriosas bramas / la iniciación de los sagrados ritos, / en tanto mueven tigres y panteras / sus hierros...» (Dario, 555). En «Friso», Rubén describe las fiestas dionisíacas: «Lírica procesión que al viento esparce / los cánticos rituales de Dionisio»; en ellos aparecen también, encadenados, dos tigres («fiera / que felino pezón nutrió en Hiscania») y dos leopardos (598). El sentido, pues, de esta reunión de «caballeros» es el de una fiesta dionisíaca de carácter religioso en la que se celebra el renacimiento de mitos imperiales. Esa exaltación religiosoerótica es también el significado de «salvaje» a que nos referimos en nota 13 . Que esta exaltación tiene carácter anticristiano lo muestra la identificación, en «La fuente», de siete panteras con los siete pecados capitales (616). 
Pero si por una parte se dejan arrebatar por el delirio de Venus, su mente contempla, como los centauros, la eterna lira de Diana:

$\mathrm{Y}$ aquellos amantes de la eterna Dea, a la dulce música de la regia rima, oyen el mensaje de la vasta idea (567).

No es sorprendente, pues, que Darío nos diga que cada «caballero» (y la inclusión de caballo en el lexema no es accidental) es «sátiro y centauro».

Dos breves citas nos servirán para concluir (y remachar) nuestro análisis del significado de los iconos /centauro/, /virgen/ y / hetaira/. Como hemos visto, la /virgen/ (/Diana/) y la /hetaira/ (/Venus/) son los dos principios de la revolución estética e histórica propuesta por Darío. /Diana/ es la «eterna armonía», la lira celestial que inspira al «vate», al «sacerdote» del Arte; pero, por ser eterna, por trascender el tiempo y la historia, puede separar al artista de su época y ser un principio de muerte. Dario parece entender por esta identidad entre Diana y Muerte tanto la trascendencia intemporal de la Belleza (en un sentido platónico) cuanto la belleza de las grandes obras del pasado: las «bellas conquistas» del imperio español que canta en «Garçonnière», y que se convierten en tradición muerta si no son dinámicamente actualizadas. El medio para esa actualización es /Venus/: el sagrado, orgiástico impulso erótico, que, inspirado en la contemplación ideal (es decir, en la visión de Diana, de la Dea-Idea), enciende en el vate-creador un salvaje impulso genésico; salvaje porque destruye tradiciones muertas, genésico porque las reconstruye en nuevas creaciones imperiales. $\mathrm{Y}$, como hemos visto, la criatura capaz de esa doble actividad, contemplación y furor genésico, es el /centauro/. El Dios-Hombre, Cristo y Anticristo, adorador y violador de la Hostia, es el arquetipo del «vate», del sacerdote que oficia su rito sacrílego en el templo del Arte y media entre las dos diosas hermanas, y, por ese acto contemplativo-erótico, crea las grandes revoluciones estéticas que, según Darío, mueven a la humanidad. El /centauro/ es, pues, el poeta modernista; más concretamente: Darío ${ }^{22}$.

${ }^{22}$ Guillermo Sucre, en un artículo en que sigue (aparentemente sin entenderlo) a Octavio Paz, interpreta Prosas profanas, y especialmente «El coloquio de los centauros», como un libro místico en el que Darío nos da una visión sagrada del ser como conciliación de opuestos: «Los extremos se juntan o se concilian; participan de un mismo secreto: ser. El mundo se revela entonces en toda su plenitud. El bien y el mal no existen...» (54). Es difícil comprender lo que tales vaguedades significan (si es que significan algo), pero es claro que Sucre ha realizado la 
Efectivamente, una vez en posesión de este sistema icónico, algunos de los más misteriosos poemas de Prosas profanas se hacen transparentes. En «Pórtico», Darío nos da su visión de la historia: una serie de encarnaciones de «la eterna Armonía» en el tiempo. Pero la dinámica de esas encarnaciones es siempre la misma: un caballero (es decir, un héroe a caballo, un centauro), inspirado por una luz virginal, realiza hazañas creadoras. En este caso el héroe-centauro es un «joven homérida», «capitán de la lírica guerra/regio cruzado del reino del arte»; combina las armas del conquistador ("yelmo de acero», «firme tizona») con la mítica montura del poeta, «listo y piafante su excelso pegaso». La luz celestial que lo inspira reúne los elementos de «castidad», «eternidad», «eucaristía», que hemos encontrado ya: en el templo del Arte, junto a la estatua de Venus, "hay una lámpara en albo carrara / de una eucarística y casta blancura» («Pórtico», 581-585). En «E1 poeta pregunta por Stella», el poeta, efectivamente, pregunta a un lirio por Stella (que es una advocación de la Virgen: Stella Matutina, el lucero de la mañana); el lirio, en el poema, es «hermano perfumado de las estrellas castas», "mano de las vírgenes»; Rubén lo compara a «los cuellos de los cisnes», «las blancas dianas de los parques ducales»; el lirio nace «con la albura de las hostias sublimes»; por él no corre «la sangre de las rosas pecadoras»; el lirio es la flor de Stella, pero Stella, a quien todos esos atributos virginales es (se nos dice en el último verso) «la hermana de Ligeia», y Ligeia es una sirena mítica, es decir, un emblema de Venus (580).

Estos elementos nos permiten resumir nuestro examen de Prosas profanas con una referencia a Epitalamio bárbaro. Darío nos describe el canto de las ninfas marinas, entre la espuma, inmediatamente antes del amanecer. En ese paisaje marino, sorprendentemente, un súbito estremecimiento paraliza el coro cantor: un centauro (Sagitario) ha robado una estrella:

Es el momento en que el salvaje caballero se ve pasar. La tribu aúlla, y el ligero caballo es un relámpago, veloz como una idea.

A su paso, asustada, se para la marea;

"¿Qué pasa?», desde el lecho pregunta Venus bella.

Y Apolo:

«Es Sagitario, que ha robado una estrella» (592-593).

difícil empresa de dedicar veinte páginas a Prosas profanas sin vislumbrar siquiera alguno de sus temas fundamentales: «Relectura de Dario», Revista de Occidente, segunda época (Madrid, 1968), 61, pp. 46-48. 
Sagitario, el centauro guerrero ${ }^{23}$, ha robado una estrella. ¿Robar una estrella? Pero sabemos muy bien quién es Stella. Nos encontramos de nuevo con el acto sacrílego central de la creación estética: la violación de la Virgen; violación que coincide con el despertar de Venus, con la puesta en marcha de las energías eróticas; y que es realizada por el centauro aristócrata, el «salvaje aristócrata»; a su grito, el pueblo se pone en marcha: «La tribu aúlla».

El estudio del contexto de Prosas profanas nos ha permitido descubrir la estructura poética de la obra; estructura que consiste en un sistema icónico de tres imágenes: la /virgen/, la /hetaira/ y el /centauro/, mediante las cuales Darío nos da su visión del arte y de la destructora y creadora revolución poética que emprende, es decir, del modernismo. Pero ese análisis contextual debe completarse con otro intertextual ${ }^{24} . \mathrm{Si}$ situamos estas imágenes junto a la dialéctica /virgen/-/femme fatale/ en la literatura europea de la época (es decir, si localizamos a Darío en su intertextualidad) descubriremos una serie de connotaciones que precisan aún más los límites del sistema.

Hemos visto que la aristocrática belleza del pasado imperial español es una de las encarnaciones de «la eterna armonía», de Diana. También lo era para el 98. Pero 98 y modernismo reaccionan de forma opuesta frente a la /virgen/. Ganivet quiere huir de ese presente europeo cuya civilización industrial ofende los valores de su tradición ${ }^{25}$. Como muy bien vio Darío, la España finisecular quiere refugiarse con la Virgen en El Escorial. Darío, por el contrario, quiere enfrentarse con la tradición

${ }^{23}$ Para el sentido poético del /centauro/ véase Javier Herrero, «Antonio Machado's Image of the Centaur», Bulletin of Hispanic Studies, 45 (1968), 37-41.

${ }^{24}$ Evidentemente, mi método exigiría una interpretación circunstancial que situase los significados ya obtenidos en las circunstancias históricas de su época, lo que los completaría con nuevas connotaciones. Por obvias razones de espacio eso no es posible aquí. Tal trabajo, sin duda, aclararía lo que esos grupos dionisíacos y «antiburgueses», embriagados de frenéticos sueños imperiales, significan en el plano político.

${ }^{25}$ Como es bien sabido, Ganivet comienza el Idearium español comparando a España con la Virgen en su advocación de Inmaculada Concepción. Pero esa Virgen, como la Virgen María, es también madre, pues en su sueño imperial creó múltiples hijas en América. Ganivet propone, sin embargo, que España debe ahora retirarse de la civilización industrial, material y burguesa y, ensimismándose en la contemplación de sus propios valores, crear una nueva España, regida por un «socialismo anárquico-nirvánico». Este significado de la /virgen/ en el 98 , tan distinto del de Darío y el modernismo, lo he estudiado en mi artículo «España como Virgen; el tradicionalismo radical de Angel Ganivet», próximo a aparecer en el homenaje que a Juan López-Morillas prepara Brown University. 
española: quiere violarla. Mediante el crimen sacrílego de la violación de la Virgen-Madre, Rubén espera fecundarla, hacerla concebir un arte nuevo, salvaje, obra en que la sagrada sangre india se mezcle a la aristocrática del pasado imperial. De esa violación surgirá un ejército de cruzados modernos que, en una orgía de destrucción y creación, moverán a los pueblos («la tribu aúlla») a nuevas construcciones imperiales. Construcciones que rechazan (y se proponen destruir; de ahí su salvajismo) la vulgaridad de la sociedad industrial y su liberal-democracia.

Pero ¿podemos precisar con mayor claridad el sentido de esa cruzada sacrílego-estética? La intertextualidad de fin de siglo nos proporciona datos clarificadores. El rito criminal que tiene lugar en el templo del Arte es una afirmación de la liberación de individuos geniales, de superhombres, de las ataduras de la democracia liberal y del socialismo. Es también un esfuerzo para reemplazar la teología cristiana tradicional por un culto al individuo que se expresa en el frenesí de las masas guiadas por minorías de líderes excepcionales. En ese mundo nuevo el vate modernista (Darío el primero) es el músico que acompaña a los «caballeros salvajes».

E1 análisis literario, pues, si es llevado a sus últimas consecuencias, nos arranca de la literatura y nos encarna en la historia. Ello es inevitable, puesto que el signo, el icón, no es una expresión intemporal, sino que, como vehículo de comunicación entre artista y lector, supone un lenguaje poético común, una escritura. La /virgen/ es Diana (griega), María (cristiana), el Cisne (siglo XIX), etc.; pero a fines de siglo adquiere un sentido específico que descubrimos en el arte de la época. Sólo mediante una dialéctica que nos lleva del texto al contexto, al intertexto, y a la circunstancia, podemos precisar el sentido de las imágenes arquetípicas de un período y un movimiento literarios. Pero esa dialéctica debe partir siempre del texto y regresar al texto; sólo así evitaremos los dogmatismos que no descubren el significado, sino que to imponen. La dialéctica es el más eficaz instrumento contra todos los fanatismos.

University of Virginia.

JAVIER HerRero 